\title{
OPTIMAL POSTHARVEST STORAGE PARAMETERS AND SHELF LIFE OF BABY SPINACH (SPINACIA OLERACEA L.)
}

\begin{abstract}
Jonas VIŠKELIS, Laboratory of Biochemistry and Technology, Institute of Horticulture, Lithuanian Research Centre for Agriculture and Forestry, Kauno g. 30, Babtai LT-54333, Kauno raj., Lithuania, j.viskelis@1sdi.lt (corresponding author) Marina RUBINSKIENE், Laboratory of Biochemistry and Technology, Institute of Horticulture, Lithuanian Research Centre for Agriculture and Forestry, Kauno g. 30, Babtai LT-54333, Kauno raj., Lithuania, m.rubinskiene@1sdi.lt Dalia URBONAVIČIENĖ, Laboratory of Biochemistry and Technology, Institute of Horticulture, Lithuanian Research Centre for Agriculture and Forestry, Kauno g. 30, Babtai LT-54333, Kauno raj., Lithuania, d.urbonaviciene@1sdi.lt ,_Department of Food Technology, Kaunas University of Technology, Radvilėnų pl. 19, LT-50254 Kaunas, Lithuania, dalia.urbonaviciene@ktu.edu Ramunè BOBINAITE், Laboratory of Biochemistry and Technology, Institute of Horticulture, Lithuanian Research Centre for Agriculture and Forestry, Kauno g. 30, Babtai LT-54333, Kauno raj., Lithuania, r.bobinaite@1sdi.lt Pranas VIŠKELIS, Laboratory of Biochemistry and Technology, Institute of Horticulture, Lithuanian Research Centre for Agriculture and Forestry, Kauno g. 30, Babtai LT-54333, Kauno raj., Lithuania, biochem@1sdi.lt , Department of Food Technology, Kaunas University of Technology, Radvilènų pl. 19, LT-50254 Kaunas, Lithuania, pranas.viskelis@ktu.lt
\end{abstract}

\begin{abstract}
This work was done to evaluate the optimal postharvest storage parameters and shelf life of baby spinach. Baby spinach (50 g) was sealed in three different polypropylene (PP) and polyethylene (PE) packaging materials: $30 \mu \mathrm{m}(\mathrm{PP}), 35 \mu \mathrm{m}(\mathrm{PE}) \& 40 \mu \mathrm{m}(\mathrm{PE})$, and were stored in darkness for 3 and 9 days at $0{ }^{\circ} \mathrm{C}, 4{ }^{\circ} \mathrm{C}, 8{ }^{\circ} \mathrm{C} \& 16{ }^{\circ} \mathrm{C}\left( \pm 1{ }^{\circ} \mathrm{C}\right)$. Total content of phenolics, soluble solids, nitrates, chlorophyll content, ascorbic acid \& spinach color (CIEL*a*b*) were measured by standard methods after 3 and 9 days of storage.

Baby spinach stored at $0 \pm 1{ }^{\circ} \mathrm{C}$ and $4 \pm 1{ }^{\circ} \mathrm{C}$ showed the best visual quality. Storage temperature had significant influence on spinach colour, but the influence of packaging was not so strong. The content of soluble solids, ascorbic acid and nitrates decreased during storage. The highest amount of ascorbic acid was retained when baby spinach were stored in $40 \mu \mathrm{m}$ PE bags at $0 \pm 1{ }^{\circ} \mathrm{C}$. When baby spinach was stored at higher temperatures $\left(4{ }^{\circ} \mathrm{C}, 8{ }^{\circ} \mathrm{C} \mathrm{\&} 16^{\circ} \mathrm{C}\right)$, the decrease in the amount of ascorbic acid ranged from $55 \%$ to $69 \%$. Baby spinach stored for 9 days at $0{ }^{\circ} \mathrm{C} \& 4{ }^{\circ} \mathrm{C}$ showed high visual and biochemical quality. Higher amounts of soluble solids and ascorbic acid were found in spinach stored in $40 \mu \mathrm{m}$ PE bags.
\end{abstract}

Keywords: postharvest storage, spinach, Spinacia oleracea L.

\section{INTRODUCTION}

Spinach (Spinacia oleracea L.) leaves accumulate large amounts of biologically active substances. It has been shown that extracts of spinach leaves retain their biological activity in both in vitro and in vivo systems because of the high amounts of natural antioxidants, i.e., flavonoids and p-coumaric acid (Bergman et al., 2001). Young, small and not overgrown spinach leaves have the highest value. Freshly cut spinach contains approximately $1000 \mathrm{mg} / \mathrm{kg}$ of flavonoids (Conte et al., 2008). However, spinach is a leafy vegetable and spoils very rapidly. Storage conditions influence its quality and shelf life. Under the usual storage conditions (at $7^{\circ} \mathrm{C}$ ), the quality of freshly cut spinach decreases significantly after 7 days. The processes of ascorbic acid degradation become very active in spinach leaves after 6 days of storage at $10{ }^{\circ} \mathrm{C}$ (Del Nobile et al., 2006). To preserve marketable spinach quality for a longer period of time, various methods of storage are being investigated; one of these is storage in a modified atmosphere. Various polymeric films permeable to $\mathrm{O}_{2}, \mathrm{CO}_{2}$ and water vapour are used for packaging under a modified atmosphere. Packaging materials influence the sensory quality of leafy green vegetables by altering the respiration rate, which affects the colour and texture of the product (Lomnitski et al., 2003). This effect is especially important when spinach is transported and stored at higher temperatures, e.g., in supermarkets. It has been reported that spinach stored in low density polyethylene (PE) packages retained higher amounts of phenolic compounds, ascorbic acid and $\beta$-carotene (Madhekar et al., 2011).

The aim of this investigation was to evaluate the influence of various packaging materials (films) and storage temperatures on various quality parameters of freshly picked baby spinach.

Copyright (C) 2015 The Authors. Published by Aleksandras Stulginskis University. This is an open-access article distributed under the terms of the Creative Commons Attribution License (CC-BY 4.0), which permits unrestricted use, distribution, and reproduction in any medium, provided the original author and source are credited. 


\section{MATERIALS AND METHODS}

Investigations were carried out at the Institute of Horticulture, Lithuanian Research Centre for Agriculture and Forestry, Biochemistry and Technology Laboratory. Baby spinach was packed in the enterprise of vegetable procession joint stock company "Salpronè". Freshly picked baby spinach of the cultivar 'Corvair' were selected for this study. Spinach leaves $(50 \mathrm{~g})$ were placed in bags and the bags sealed. Three types of bags were used: $30 \mu \mathrm{m}$ polypropylene (PP) (Amcor Flexibles, Bristol, UK); $35 \mu \mathrm{m}$ polyethylene ( $\mathrm{PE}_{1}$ ) (Amcor Flexibles, Bristol, UK) and $40 \mu \mathrm{m}$ polyethylene $\left(\mathrm{PE}_{2}\right)$ (Antifog Film BOPP, PlastiCaen, France). The packages were stored in darkness for 3 and 9 days at $0 \pm 1{ }^{\circ} \mathrm{C}, 4 \pm 1{ }^{\circ} \mathrm{C}, 8 \pm 1{ }^{\circ} \mathrm{C}$, and $16 \pm 1{ }^{\circ} \mathrm{C}$. Samples were selected at random.

The sensory properties and chemical composition of the prepared products were investigated after 3 and 9 days of storage. Ascorbic acid was measured by titration with 2,6-dichlorphenolindophenol sodium chloride solution (AOAC, 1990); soluble solids were measured with an ATAGO digital refractometer. The amount of nitrates was measured potentiometrically with an ion-selective electrode. The total content of phenolics was measured with the Folin-Ciocalteu procedure (Pavia et al., 2004). Colour was measured with a MiniScan XE Plus spectrophotometer (Hunter Associates Laboratory, Inc., Reston, Virginia, USA). The CIEL*a*b* colour parameters were recorded as $\mathrm{L}^{*}$ (lightness), $\mathrm{a} *$ (redness/greenness) and $\mathrm{b}^{*}$ (yellowness/blueness). The chroma $\left(\mathrm{C}^{*}=\left(\mathrm{a}^{* 2}+\mathrm{b}^{* 2}\right)^{1 / 2}\right)$ and hue angle $\left(h^{\circ}=\arctan \left(b^{*} / a^{*}\right)\right)$ were also calculated. The investigations were conducted with three replicates. Statistical processing of results was made with the help of MS Excel and software package SELEKCIJA. The spinach leaves chemical compounds results were presented as the averages of 3 measurements with the standard errors of the means. Colour characteristics (as the averages of 3 measurements) data was evaluated statistically using two-way factorial ANOVA analysis (Tarakanovas and Raudonius, 2003). Fisher's LSD test and the determination coefficient were calculated at the probability level $\mathrm{P} \leq 0.05$.

\section{RESULTS}

The humidity was lower in the packages of all types stored for 9 days at $8 \pm 1{ }^{\circ} \mathrm{C}$ and $16 \pm 1{ }^{\circ} \mathrm{C}$. After 9 days of storage, the visual quality of the spinach stored at $8 \pm 1{ }^{\circ} \mathrm{C}$ did not change. However, the taste of the spinach leaves decreased in quality, especially in the $40 \mu \mathrm{m} \mathrm{PE} \mathrm{P}_{2}$ packages. Baby spinach retained a fresh odour after 3 days of storage at $16 \pm 1{ }^{\circ} \mathrm{C}$, but its texture and taste became slightly worse. After 9 days of storage, for all types of packaging material, the spinach leaves became tasteless. After 3 and 9 days of storage, good sensory properties (odour, texture and taste) were found in the spinach leaves kept at $0 \pm 1{ }^{\circ} \mathrm{C}$ and $4 \pm 1{ }^{\circ} \mathrm{C}$ and packed in $30 \mu \mathrm{m} \mathrm{PP}$ and $35 \mu \mathrm{m}$ PE 1 film bags. The texture scores ranged from 4.5 to 5.0, and the taste scores ranged from 4.0 to 5.0. Baby spinach stored at $0 \pm 1{ }^{\circ} \mathrm{C}$ in $30 \mu \mathrm{m}$ PP film bags was found to show the best odour and taste.

The baby spinach cultivar Corvair accumulated $5.1 \%$ of soluble solids. During storage, the content of soluble solids in the spinach varied depending on the storage conditions and packaging material (Figure 1). Nevertheless, the content of soluble solids did not change in spinach stored at $0 \pm 1{ }^{\circ} \mathrm{C}$, and the highest content of soluble solids was found in the spinach leaves that were stored in $40 \mu \mathrm{m} \mathrm{PE}$ film bags. In baby spinach stored at $4 \pm 1{ }^{\circ} \mathrm{C}$, the soluble solids content showed differences only after 9 days. A lower content of soluble solids was found in the leaves that were packed in $30 \mu \mathrm{m}$ PP film bags. Higher storage temperatures $\left(8 \pm 1{ }^{\circ} \mathrm{C}\right.$ and $\left.16 \pm 1{ }^{\circ} \mathrm{C}\right)$ had a greater impact on the content of soluble solids. In the $35 \mu \mathrm{m} \mathrm{PE}$ and $40 \mu \mathrm{m} \mathrm{PE}$ film bags, the amount of soluble solids in spinach leaves decreased by $8 \%$ and $6 \%$, respectively. After 9 days of storage, the highest content of soluble solids was found in the spinach leaves packed in $40 \mu \mathrm{m} \mathrm{PE}_{2}$ film bags.
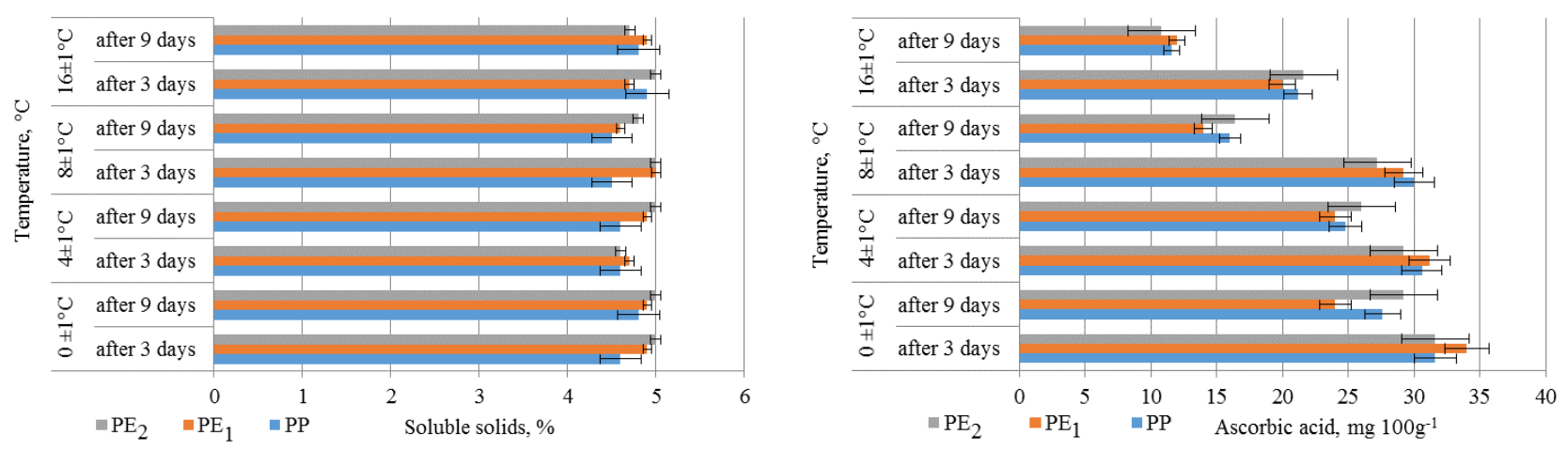

Figure 1. Influence of storage conditions and packaging material on soluble solids and ascorbic acid content of baby spinach $\left(\mathrm{PP}-30 \mu \mathrm{m} ; \mathrm{PE}_{1}-35 \mu \mathrm{m} ; \mathrm{PE}_{2}-40 \mu \mathrm{m}\right)$

The amount of ascorbic acid in freshly picked baby spinach was $32.4 \mathrm{mg} 100 \mathrm{~g}^{-1}$. During storage, the decrease in the amount of ascorbic acid in the spinach leaves ranged from $7.6 \%$ to $50 \%$ (Fig. 1). Higher amounts of ascorbic acid were retained when spinach was stored at $0 \pm 1{ }^{\circ} \mathrm{C}$ and $4 \pm 1{ }^{\circ} \mathrm{C}$ for shorter ( 3 day) periods. The decrease in the ascorbic acid content of the spinach stored at the highest temperature $\left(16 \pm 1{ }^{\circ} \mathrm{C}\right)$ ranged from $35.7 \%$ to $41.7 \%$. The size of the 
decrease depended on the packaging film used. After 9 days of storage at $0 \pm 1{ }^{\circ} \mathrm{C}$ and $4 \pm 1{ }^{\circ} \mathrm{C}$, higher amounts of ascorbic acid were retained in baby spinach packed in $40 \mu \mathrm{m} \mathrm{PE}_{2}$ film bags. A positive correlation has been found between the soluble solids and ascorbic acid content of spinach and the quality of the spinach (Spinardi et al., 2010).

The storage conditions and packaging material influenced the total content of phenolics of baby spinach (Figure 2). A higher total content of phenolics was found in spinach leaves that were stored for 3 days at $0 \pm 1{ }^{\circ} \mathrm{C}, 8 \pm 1$ ${ }^{\circ} \mathrm{C}$ and $16 \pm 1{ }^{\circ} \mathrm{C}$ in packages made of $35 \mu \mathrm{m} \mathrm{PE}$ film. In general, the concentration of phenolic compounds decreased slightly during storage. In freshly picked baby spinach, the content of nitrates was $3186 \mathrm{mg} \mathrm{kg}^{-1}$. During storage, the decrease in the content of nitrates ranged from $7.3 \%$ to $21.7 \%$ depending on the storage conditions and packaging material (Figure 2). Baby spinach stored in $30 \mu \mathrm{m}$ PP film bags retained a higher content of nitrates. The lowest amount of nitrates $\left(2417 \mathrm{mg} \mathrm{kg}^{-1}\right)$ was detected in baby spinach stored in $\mathrm{PE}_{2}$ film bags at $16 \pm 1{ }^{\circ} \mathrm{C}$.
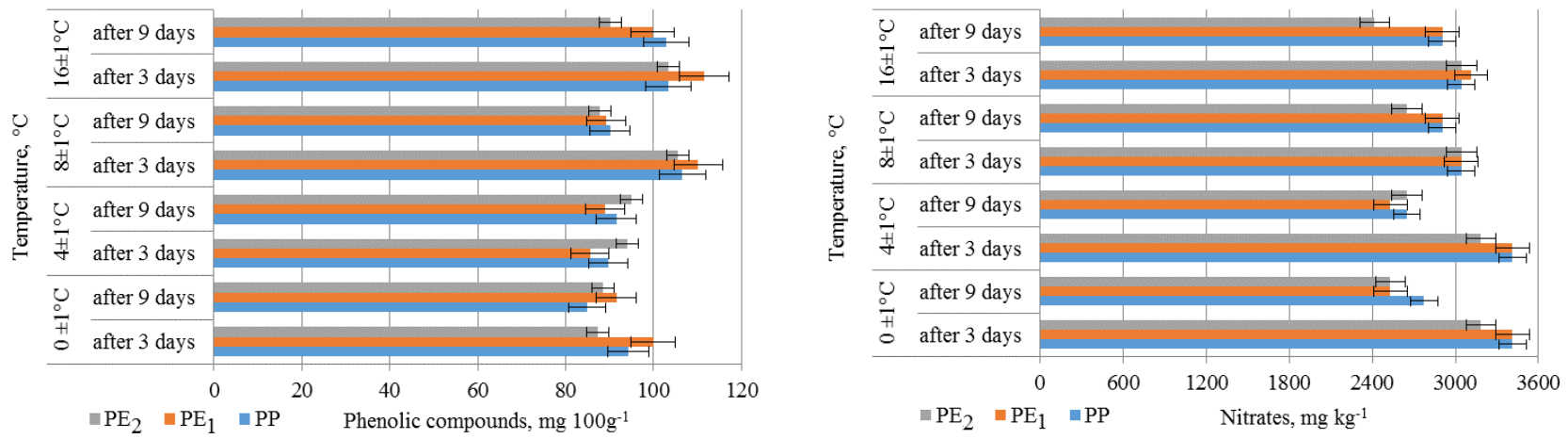

Figure 2. Influence of storage conditions and packaging material on the total content of phenolic compounds and the content of nitrates in baby spinach $\left(\mathrm{PP}-30 \mu \mathrm{m} ; \mathrm{PE}_{1}-35 \mu \mathrm{m} ; \mathrm{PE}_{2}-40 \mu \mathrm{m}\right)$

The storage temperature had the greatest impact on the colour indices of the product. Statistically significant variation was found in the CIEL*a*b* colour values of the spinach (Fig. 3). Lightness (L*) and greenness (negative values of $\mathrm{a}^{*}$ ) are the most important colour coordinates for evaluating the visual quality of baby spinach. The lightness index $\left(\mathrm{L}^{*}\right)$ of baby spinach stored for 3 days in $30 \mu \mathrm{m}$ PP film bags was slightly higher (on average, $41.7 \%$ ) than that found in other storage conditions. However, this tendency was not statistically significant.
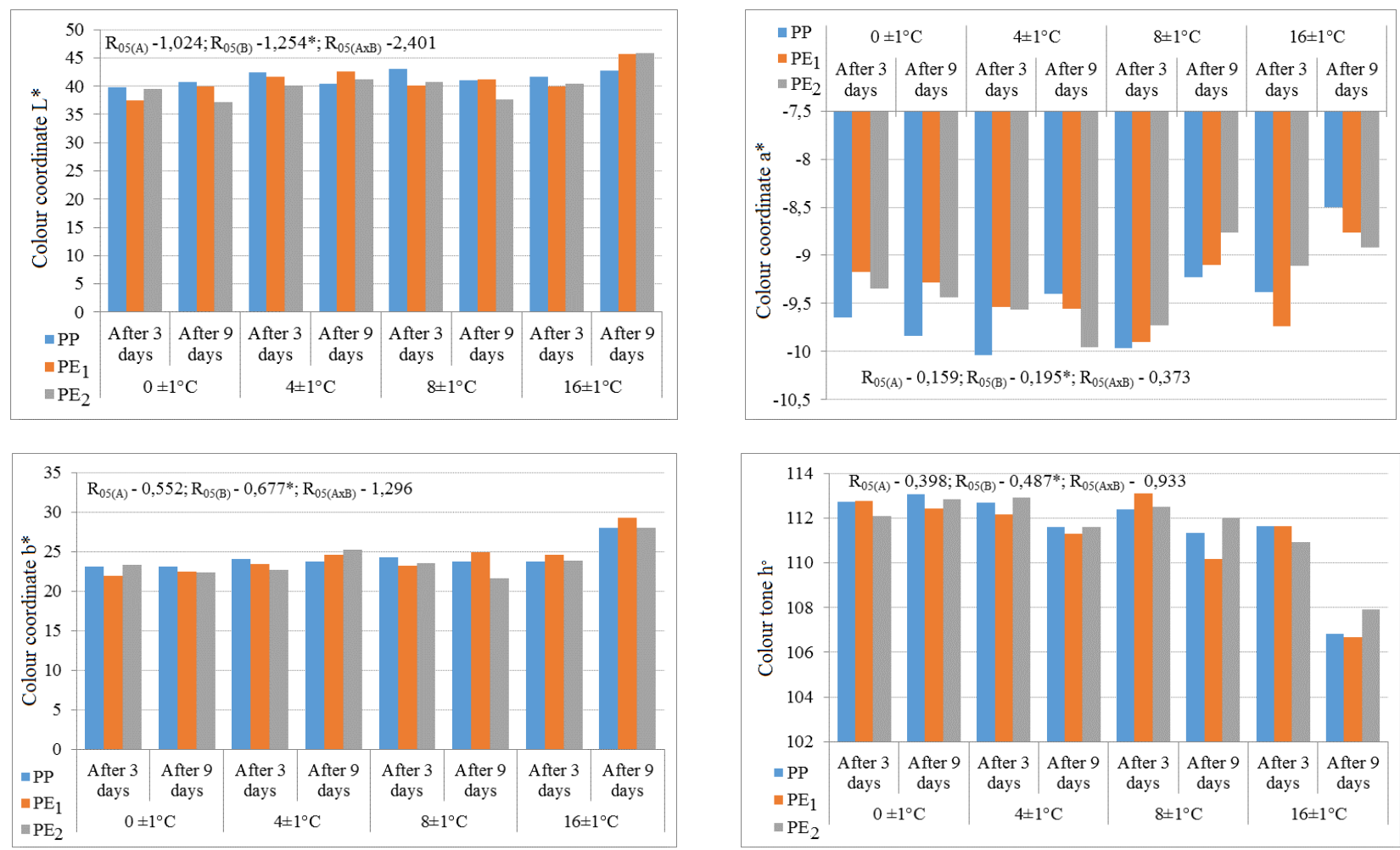

Figure 3. Influence of storage conditions and packaging material on lightness $\mathrm{L}^{*}$, colour coordinates $\mathrm{a}^{*}, \mathrm{~b}^{*}$, tone $\mathrm{h}^{\circ}$ of baby spinach (PP - $30 \mu \mathrm{m} ; \mathrm{PE}_{1}-35 \mu \mathrm{m} ; \mathrm{PE}_{2}-40 \mu \mathrm{m}$ ). Factor $\mathrm{A}$ is packaging material, factor $\mathrm{B}$ - storage temperature

The lightness of baby spinach stored at the highest temperature $\left(16 \pm 1{ }^{\circ} \mathrm{C}\right)$ showed a relative increase. The increase in the lightness index was more pronounced in spinach leaves that were stored in $\mathrm{PE}_{1}$ and $\mathrm{PE}_{2}$ film bags (14.3\% and $13.6 \%$, respectively) (Figure 3). The storage temperature was found to have the greatest impact on the 
colour coordinate $\mathrm{a}^{*}$ and the colour tone $\left(\mathrm{h}^{\circ}\right)$ of the baby spinach (Figure 3 ). The colour coordinate $\mathrm{a}^{*}$ of the spinach stored for 3 days at $4 \pm 1{ }^{\circ} \mathrm{C}$ and $8 \pm 1{ }^{\circ} \mathrm{C}$ in $30 \mu \mathrm{m}$ PP film bags was the most highly negative (i.e., the leaves stored in the $30 \mu \mathrm{m}$ PP film bags were the greenest in colour). After 9 days of storage, the greenness value $\left(-\mathrm{a}^{*}\right)$ decreased, showing that the green colour, i.e., the concentration of chlorophylls in baby spinach, was reduced or that these compounds were degraded. This index $\left(-\mathrm{a}^{*}\right)$ changed most markedly when the baby spinach was stored at the higher temperatures $\left(8 \pm 1{ }^{\circ} \mathrm{C}\right.$ and $16 \pm 1{ }^{\circ} \mathrm{C}$ ). During storage, the yellowness (colour coordinate $\left.\mathrm{b}^{*}\right)$ of the baby spinach increased (Figure 3). After 9 days of storage at $8 \pm 1{ }^{\circ} \mathrm{C}$ and $16 \pm 1{ }^{\circ} \mathrm{C}$, the values of the colour coordinate $\mathrm{b}^{*}$ showed statistically significant differences. This tendency was observed in all types of packaging. The values of the colour coordinate $\mathrm{b}^{*}$ increased most strongly in the baby spinach packed in the $30 \mu \mathrm{m} \mathrm{PE}$ film bags. The mean value of $\mathrm{h}^{\circ}$ in the baby spinach was $112.5^{\circ}$. This value indicates that the colour of the spinach leaves was green but that the leaves also had a slightly yellowish shade (the colour tone of green is equal to $180^{\circ}$ ). The yellowish shade indicates the presence of carotenoids in spinach (Vernon, 1960). The value of $\mathrm{h}^{\circ}$ showed the strongest decrease in the baby spinach stored for 9 days at $16 \pm 1{ }^{\circ} \mathrm{C}$. During storage at $0 \pm 1{ }^{\circ} \mathrm{C}, 4 \pm 1^{\circ} \mathrm{C}$ and $8 \pm 1{ }^{\circ} \mathrm{C}$, the $\mathrm{h}^{\circ}$ value remained most stable in the $40 \mu \mathrm{m} \mathrm{PE}_{2}$ film bags.

\section{CONCLUSIONS}

Spinach leaves stored at $0-4{ }^{\circ} \mathrm{C}$ in $30 \mu \mathrm{m}$ PP and $35 \mu \mathrm{m} \mathrm{PE}_{1}$ film bags retained the best texture, taste and characteristic odour of freshness for up to nine days. When stored at $16{ }^{\circ} \mathrm{C}$ (for example, in supermarkets) the characteristic taste of baby spinach is only retained for up to 3 days. Smaller changes in soluble solids, ascorbic acid and the concentration of phenolics were detected in baby spinach stored in $40 \mu \mathrm{m} \mathrm{PE}$ film bags at $4 \pm 1{ }^{\circ} \mathrm{C}$. The amount of nitrates decreased during the storage of baby spinach, although slightly higher amounts of nitrates were found in spinach packed in $30 \mu \mathrm{m} \mathrm{PP}$ and $35 \mu \mathrm{m} \mathrm{PE}$ film bags and stored for 3 days. Storage temperature affects the colour of spinach leaves (significant at $\mathrm{P} \leq 0.05$ difference), but the packaging material did not had influence on spinach leaves colour. The storage temperature of the spinach had the greatest influence on the colour coordinate $\mathrm{a}^{*}$ and the colour tone $\mathrm{h}^{\circ}$.

Acknowledgements. This work was supported by a grant from the Research Council of Lithuania, No. SVE-02/2011.

\section{REFERENCES}

1. AOAC. 1990. Vitamin C (ascorbic acid) in vitamin preparations and juice. Official Methods of Analysis, $15^{\text {th }}$ ed., AOAC Inc. Arlington, VA, pp. 1058.

2. Bergman, M., Varshavsky, L., Gottlieb, H. E., Grossman, S. 2001. The antioxidant activity of aqueous spinach extract: chemical identification of active fractions. Phytochemistry, Vol. 58, Iss. 1, pp. 143-52. http://dx.doi.org/10.1016/S0031-9422(01)00137-6

3. Conte, A., Conversa, G., Scrocco, C., Brescia, I., Laverse, J., Elia, A. Del Nobile, M. A. 2008. Influence of growing periods on the quality of baby spinach leaves at harvest and during storage as minimally processed produce. Postharvest Biology and Technology, Vol. 50, pp. 190-196. http://dx.doi.org/10.1016/j.postharvbio.2008.04.003

4. Del Nobile, M. A., Baiano, A., Benedetto, A., Massignan. 2006. Respiration rate of minimally processed lettuce as affected by packaging. Journal of Food Engineering, Vol. 74, Iss. 1, pp. 60-69. http://dx.doi.org/10.1016/j.jfoodeng.2005.02.013

5. Lomnitski, L., Bergman, M., Nyska, A., Ben-Shaul, V., Grossman, S. 2003. Composition, efficacy, and safety of spinach extracts. Nutrition and Cancer, Vol. 46, Iss. 2, pp. 222-231. http://dx.doi.org/10.1207/S15327914NC4602_16

6. Madhekar, R. D., Mungika, A. M. 2011. Storage of leaf juice extracted from spinach (Spinacia oleraceae L.). Science \& Culture, Vol. 77, Iss. 3-4, pp. 141-142.

7. Pavia, D. L., Lampman, G. M., Kriz, G. S., Engel, R. G. 2004. Isolation of chlorophyll and carotenoid pigments from spinach. Journal of Chemical Education, Vol. 81, pp. 385-387.

8. Spinardi, A., Cocetta, G., Baldassarre, V., Ferrante, A., Mignani, I. 2010. Quality changes during storage of spinach and lettuce baby leaf. Acta Horticulturae, (ISHS) Vol. 877, pp. 571-576.

9. Tarakanovas, P., Raudonius, S. 2003. Statistical analysis for agronomic research using computer programs ANOVA, STAT, SPLIT-PLOT from software package SELEKCIJA and IRRISTAT, Lithuanian University of Agriculture, pp. 58. (In Lithuanian)

10. Vernon, L. P. 1960. Spectrophotometric determination of chlorophylls and pheophytins in plant extracts. Analytical Chemistry, Vol. 32, Iss. 9, pp. 1144-1150. http://pubs.acs.org/doi/abs/10.1021/ac60165a029 